\title{
The Relationship among Total Quality Management, Operational Performance and Competitive Advantage in the Jordanian Banking Sector
}

\author{
MOHAMMAD ALI IBRAHIM AL KHASABAH, HAYATUL SAFRAH SALLEH, \\ NIK HAZIMAH NIK MAT, SITI NUR ATIKAH ZULKIFFLI \\ Faculty of Business, Economics and Social Development \\ University Malaysia Terengganu \\ 21030 Kuala Terengganu \\ MALAYSIA
}

\begin{abstract}
The purpose of this study is to examine the relationship between total quality management (TQM), operational performance, and competitive advantage in the Jordanian banking sector, and also to determine whether operational performance mediates the relationship between TQM and competitive advantage. The data from 336 respondents were validated and tested using the partial least squares structural equation modeling. This study was conducted using a self-administered questionnaire distributed among managers of the Jordanian Banking Sector. The result revealed that TQM has a positive significant effect on competitive advantage at 0.001 level of significance $(\beta=0.393, \mathrm{t}=7.113, \mathrm{p}<0.001)$. The results also showed that TQM had an important effect on operational performance at the significance level of $0.001(\beta=0.632, t=14.846, p<0.001)$. Also, the study discovered that operational performance plays a role as a mediator on the relationship between TQM and competitive advantage in the Jordanian banking sector at the 0.001 level; $\beta=0.257$, $t$-value $=6.696$, $p$-value $=$ 0.000 . The study is beneficial for the banking sector, financial institutions, and other organizations that seek to improve their competitive advantage among their competitors through proper employment of TQM dimensions namely: top-management, customer focus, continuous improvement, employee management, and process management, beside improving operational performance in different activities.
\end{abstract}

Key-Words: - TQM, Competitive Advantage, operational Performance, Jordanian Banking Sector.

Received: April 24, 2021. Revised: January 16, 2022. Accepted: January 29, 2022. Published: February $16,2022$.

\section{Introduction}

Various economic sectors, including the banking, have witnessed a sharp increase in the intensity of competition whether at the local, regional or global level, as a result of the tremendous development in communication systems and technologies and the rapid change in the banking environment. These increasing developments have led to an increase in the number of competitors, the methods of competition, and the diversity of the desires and needs of current and future customers [1]. Therefore, like other countries, Jordan started to review many laws regulating banking work to update them to keep pace with developments in the global banking environment and maintain the vitality and effectiveness of this sector [2]. These reforms included amending many regulations and legislation to encourage banks to grow, stabilize and absorb the consequences of banking globalization and remove many of the restrictions that were restricting the freedom of these banks to work and compete. The purpose of these banking reforms was to increase and encourage competition among banks operating in Jordan and improve the performance of the banking sector [3].

The Central Bank of Jordan has also encouraged mergers among smaller banks to help troubled banks from their financial problems, creating strong banks that are competitive with large banks locally, regionally, and globally [3]. Also, Jordanian banks have implemented a system of banking governance to enhance the performance of banks, increase transparency in competition between Jordanian banks' conditions. moreover, Jordanian banks have adopted competitive strategies applied in many countries such as cost leadership strategy and diversification strategy as strategies that help serve and maintain customers and respond to their desires and needs [1]. Despite all these, the competitive advantage among Jordanian banks remained weak. 
Where the top five banks, for example, account for $59.42 \%$ of total operating assets, $59.45 \%$ of total deposits in Jordanian banks, $60.52 \%$ of total net profit in Jordanian banks, and 53\% of the total number of branches operating in Jordan [4].

All these advances in competitive conditions have been accompanied by an evolution in the desires and needs of customers as an inevitable consequence of global openness [5]. This prompted Jordanian banks to search for a strategic approach that ensures the provision of high-quality products and services [6, 7] Consequently, banks have viewed TQM as a competitive advantage within the context of a resource-based view of an organization. Theoretically, this may happen if TQM is seen as a hallmark of the capabilities of the organizations [8].

The academic literature dealt with analyzing the relationship between TQM and competitive advantage, as shown by studies $[9,10,11,12,13$, 14], which indicated a positive and strong relationship between TQM and competitive advantage. On the other hand, some studies indicated that TQM is not associated with competitive advantage [15]. Finally, there are some studies that indicated a positive association between some TQM practices and competitive advantage [16]. Therefore, organizations apply TQM to improve their competitive advantages and to show high levels of benefits to improve organizational performance $[17,18,19,20]$.

According to [21] TQM is used as a way to improve performance and competitiveness. Also, [22] added that organizations that adopt TQM and pursue product quality will improve their competitive advantage, business success, and differentiate their products. However, it is not known how large a role of performance is as a mediating between TQM and competitive advantage. While there was a lack of studies that investigate the relationship between TQM, performance, and Competitive Advantage. Therefore, this study aims to examine a framework identifying the relationships among TQM, operational performance, and Competitive Advantage. This study also aims to investigate the mediating role of operational performance in explaining the relationship between TQM and Competitive Advantage in the Jordanian banking sector.

The significance of this study lies on the contributions it makes, both at the theoretical and applied levels. On the theoretical level, it supports the theoretical basis on the impact of each TQM dimension on the competitive advantage in the Jordanian banking sector. In addition, this study filled the knowledge gap identified in previous studies about a lack of studies examining the impact of TQM on competitive advantage. Furthermore, this study provided empirical evidence that TQM affects competitive advantage, which is in agreement with previous studies $[9,10,11]$, In addition to its many practical contributions, this study has enhanced the perceptions of TQM, operational performance and competitive advantage by providing managers in Jordanian banks with frameworks their operational performance will improve, which in turn will improve Jordanian banks' competitive advantage

This study also contributed to showing the importance of operational performance as a mediating variable in the relationship between TQM and competitive advantage in the banking sector in Jordan. Therefore, managers should focus their efforts on providing diverse, unique and highquality services at low prices compared to competitors, reducing the time taken to fulfill customer orders, and fulfilling customer orders on time. Good implementation of these operational performance requirements as well as the practice of TQM ensure that banks improve them

competitive advantage.

\section{Literature Review}

\subsection{Competitive Advantage}

Competitive advantage can be defined as the implementation of strategies for organization based on investing its resources and features at a higher level than competitors in the same market or industry [23]. Also [24] asserts that competitive advantage occurs when a company adopts strategies and resources that it directly controls and cannot be simultaneously enforced by existing or potential competitors. in general, competitive advantage refers to the following capabilities that an organization possesses when compared to its competitors, such as, low prices, high quality, high reliability, and shorter delivery time, these capabilities will improve the company's overall performance [25]. According to [23] there are three types of strategies discussed by Porter at 1980 these are: differentiation, cost leadership, and focus.

Researchers used different indicators to measure competitive advantage. For example, [26, 27] identified differentiation and cost leadership. [28] In their study exhibited cost, financial, flexibility, quality and delivery. In addition, [29] presented production cost, production quality, production delivery, and production flexibility. Also, [30] 
limited these indicators: Unit cost. Fast delivery, Flexibility to change volume, Inventory turnover, and Cycle time. The present study utilizes differentiation and cost leadership.

\subsection{TQM}

TQM philosophy includes an organizational commitment to continuous improvement and meeting customer desires and needs [31]. Also, TQM is an organizational culture that supports the achievement of continuous customer satisfaction through an integrated system of technologies, tools, and training [12].

There is a consensus that organizations should use several principles in an integrated manner to ensure the successful implementation of TQM. Moreover, several studies have been conducted with the aim of knowledge of practices key to the success of TQM [32, 33, 34]. None of these studies presented a common set of practices for successful TQM implementation, although some quality award models provide a successful framework in implementing TQM and evaluating its business results such as the European Quality Award, Malcolm Baldrige National Quality Award, Deming Award [35].

The study by [9] identified Top management support, employee involvement, employee empowerment, Customer focus, Training, Reward and recognition, and Culture as components of TQM that were used as a source of competitive advantage in the Bangladeshi beverage organization. While the study by [10] presented the following critical success factors of TQM Leadership, People management, Information and analysis, and Customer focus. Through the rigorous review of the TQM literature, the current study utilizes five dimensions of TQM: top-management, customer focus, continuous improvement, employee management, process management, the reasons for identifying these practices are: They have been used extensively and frequently (the highest frequency) by various researchers, especially in the service sectors [36]. Finally, four of these factors are used as indicators in many international quality awards such as the Malcolm Baldrige Award, the New Zealand Business Excellence Award, the European Quality Award, the Egyptian Quality Award, and the Japanese Quality Award [37].

\subsection{Operational Performance}

Operational Performance is to make all business units within the organization work in alignment to ensure that they work together to achieve essential business goals [38]. Operational performance refers to an organization's ability to reduce management costs, time to fulfill orders to customers and improve raw material utilization efficiency and distribution capacity [39]. Operational performance has an important meaning for organizations, as it creates high-quality products, improves production efficiency, and makes customers more satisfied, which ultimately leads to an increase in the organization and its profits [40]. [41] also defined operational performance as a performance related to an organization's internal processes, such as product quality, productivity, and customer satisfaction.

Many previous studies used different indicators to measure operational performance. [42] used four indicators including cost, delivery, flexibility, and quality. Also, [43] used four indicators: Flexibility, Delivery time, Customer satisfaction and Fulfilling quality requirements. [44] in their study used the following dimensions to measure operational performance: Cost, Quality, Reduced defects/scrap, Delivery, Innovation, Capacity utilization, and Minimum Work in Progress.

\subsection{TQM and Competitive Advantage}

Competitive advantage is defined as an organization's advantage over competing organizations that is gained by providing more value to the customer, either by lower product prices or by providing greater services and benefits that justify the price increase [45], because adopting TQM leads to reducing costs, improving product quality, reducing production time, improving delivery performance, and enabling faster product delivery [46]. The application of TQM will improve the flexibility of the organization and enable it to change the volume of its products quickly and thus helps to achieve a competitive advantage [13]. Besides, many studies have confirmed that TQM is an important source of competitive advantage such as $[9,10,11,14,47,48]$, Thus, the following hypotheses is proposed

\section{H1: TQM has a positive significant effect on competitive advantage in the Jordanian banking sector}

\subsection{TQM and Operational Performance}

Several studies have examined the relationship between TQM and operational performance. for example, [49] showed that TQM has a significant positive impact on operational performance in terms of improving quality, reducing cost, reducing time Delivery, and increasing flexibility. [20] and [44] added that there is a positive impact of TQM 
application on operational performance in case of combining with total production maintenance. [50] also found that there exists a positive relationship practiced between TQM and operational performance in both types of services and manufacturing industries in India. This relationship is necessary to maintain the quality of work as well as to enhance the level of competition in society. The study by [51] indicated a positive relationship between continuous improvement, system automation, employee training, and operational performance of the Kenya Revenue Authority. Also, the results of the [34] study revealed that TQM practices have an important and positive impact on the operating performance of ISO 9001: 2008 certified manufacturing organizations in Ethiopia. Thus, the following hypothesis is proposed

H2: TQM has a positive significant effect on operational performance in the Jordanian banking sector

\subsection{Operational Performance and Competitive Advantage}

[52] confirms that the organization's ability to operate in competitive environments depends to a large extent on the ability to gain knowledge and innovation in operational performance, and this is achieved through the integration of information technology and human capital to enhance strategic decisions related to customers, suppliers, and competitors, thus enhancing the overall competitive performance of the organization. Moreover, [53] adds that the operational performance in innovative organizations is an indicator of the effectiveness of the organization in achieving its goals, which ultimately leads to growth and profitability, which enhances the competitiveness of the organization. Also, [54] conducted a study that confirmed its results that organizations that apply ISO 9000 and TQM have better operational performance in terms of quality and inventory management, which is reflected in their competitiveness and access to international classifications. Thus, the following hypothesis is proposed

\section{H3: Operational performance has a positive} significant effect on competitive advantage in the Jordanian banking sector

\subsection{Operational Performance as a Mediator between TQM and Competitive Advantage}

Some studies have dealt with operational performance as a mediator between various variables such as $[55,56,57,58,59]$. According to [60] many TQM practices such as managing information systems, relationships with suppliers, training, and other practices that positively impact operational performance and that the effective management of these practices will be reflected positively to improve efficiency, profitability and increase the company's market share. [61] also showed that TQM practices significantly impact organizational performance and that it is imperative for organizations looking for a competitive advantage to be concerned with TQM practices and especially strategies for continuous improvement of their operations. Therefore, [51] confirmed that unless adopts TQM practices such as continuous improvement, employee training, and system automation in the changing business environment, achieving operational excellence will be a difficult task Thus, the following hypothesis is proposed

H4: Operational Performance mediates the relationship between TQM and competitive advantage in the Jordanian banking sector.

\section{Research Framework}

The research framework is shown in Figure 1 that shows the relationship between TQM as an independent variable and competitive advantage as a dependent variable, where operational performance is the mediating variable.

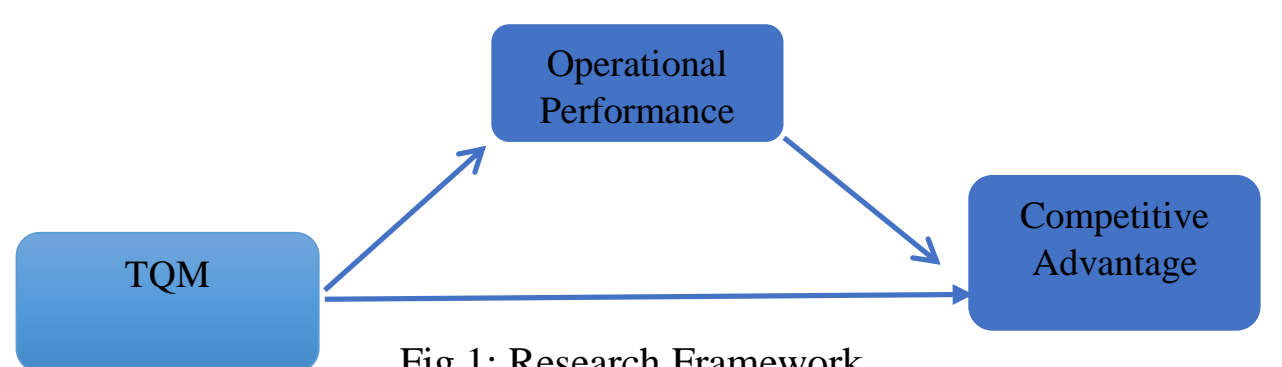

Fig.1: Research Framework 


\section{Methodology}

\subsection{Research Design}

This study employed a descriptive cross-sectional survey research design in collecting data from the respondents. in which the research effect is limited to study measurements only, but does not overlap with the research settings [62].

\subsection{Population and Sample}

The unit of analysis in this study is managers of Jordanian banks. According to the Association of the banks in Jordan, the total number of managers in 13 commercial banks, and 3 Islamic banks, are 2237. Based on the guideline reported by [63], a sample size of 331 will be sufficient. Nevertheless, the size of the sample was increased by $20 \%$ from the population to minimize error in sampling and to take care of the nonresponse rate issue [64]. Hence, 448 managers were selected as the total number of questionnaires to administer However, 336 valid questionnaires were retrieved, with a response rate of $75 \%$. The unit of analysis for this study was the managers in Jordanian banks. However, 336 questionnaires were valid for statistical analysis.

\subsection{Variable Measurement}

In terms of variable measurement, this study used five dimensions with a total of 31 items to measure TQM. These dimensions are top management, customer focus, continuous improvement, employee management, and process management. These items were adopted from [35] Competitive Advantage was measured by using thirteen items. Six items $(1,2,3$, 7,9 , and 10) were derived from [65] and [21]. Items 4 and 11 from [27]. Finally, five items (5, 6, 8, 12, and 13) from [26]. Also, eight elements taken from [66] were used to measure operational performance. All measurement items were calculated through perceptual questions on a five-point Likert scale with endpoints of "strongly disagree (1) and strongly agree (5).

\subsection{Data Collection Instrument}

The questionnaire is divided into four sections. The first section is to require demographic data of the respondents. The second section consists of five dimensions to measure TQM, with 31 items adapted from [35]. The third section consists of Competitive advantage with 13 items adapted from [21, 27, 65]. The fourth section includes 7 items indicating operational performance adapted [66]. A five-point Likert scale was used, ranging from $5=$ strongly agree to $1=$ strongly disagree to collect the responses.

\subsection{Data Analysis Strategy}

The current study used Competitive advantage as dependent variable and TQM as independent variable while operational performance used as mediator variable. Smart pls was used to test the data of the current study. The data were analyzed in two steps: the first step was to test the measurement model and the second step was to test the structural model.

\section{Analysis and Result}

\subsection{Assessment of the Measurement Model}

The measurement model was evaluated in order to ensure the reliability and validity of the model using Convergence validity and Discriminant validity, beside Cronbach's Alpha criterion to evaluate constructs' internal consistency reliability [67].

\subsubsection{Convergent Validity}

Convergent validity is a statistical test to show if there is any conflict between measurements and it is also used to provide the level of agreement between relevant indicators for the same concept [68]. According to [69] researchers must check some different tests such as composite reliability, outer loading, and Average Variance Extracted (AVE), which must achieve at least their minimum values of $0.60,0.60$, and 0.50 respectively to test the convergent validity. But for an AVE, 0.40 can be accepted because Fornell and Larcker assert that if the AVE is less than 0.50 , but the composite reliability is higher than 0.60 , the convergence validity of the construct is still sufficient [70]. also, Cronbach's Alpha criterion was used to assess constructs' internal consistency reliability and the threshold value is 0.7 [69].

Table 1 presents the convergent validity results of the general CFA model for the study in which they

achieved acceptable standard external loads of more than 0.60 except for four items (CA8, CA10, CA11 and CA12) whose loads were less than 0.60 in line with what was recommended to remove indicators with external loads between 0.40 and 0.70 from the scale, especially when the indicator is deleted indicating a composite reliability increase or AVE, where the check was rechecked four times, each 
time the item less than 0.60 was excluded until the AVE value rose above the 0.50 threshold and this did not affect the validity of the content [71]. AVE and CR were more than 0.50 and 0.60 , respectively. This confirms that all elements have sufficient reliability to measure their respective structures.

Table 1. The Convergent Validity Analysis

\begin{tabular}{|c|c|c|c|c|c|}
\hline First-order Construct & Items & $\begin{array}{c}\text { Cronbach's } \\
\text { Alpha }\end{array}$ & $\begin{array}{c}\text { Factor } \\
\text { loading }\end{array}$ & $\mathbf{C R}$ & AVE \\
\hline \multirow{7}{*}{ Top management } & TM 1 & \multirow{7}{*}{0.891} & $0.760^{\circ}$ & \multirow{7}{*}{0.915} & \multirow{7}{*}{0.605} \\
\hline & TM 2 & & 0.783 & & \\
\hline & TM 3 & & 0.754 & & \\
\hline & TM 4 & & 0.753 & & \\
\hline & TM 5 & & 0.818 & & \\
\hline & TM 6 & & 0.775 & & \\
\hline & TM 7 & & 0.799 & & \\
\hline \multirow{6}{*}{ Customer Focus } & CF 1 & \multirow[t]{6}{*}{0.834} & 0.758 & \multirow{6}{*}{0.879} & \multirow{6}{*}{0.548} \\
\hline & CF 2 & & 0.731 & & \\
\hline & CF 3 & & 0.749 & & \\
\hline & CF 4 & & 0.741 & & \\
\hline & CF 5 & & 0.823 & & \\
\hline & CF 6 & & 0.628 & & \\
\hline \multirow{5}{*}{ Continues improvement } & CI 1 & \multirow{5}{*}{0.853} & 0.795 & \multirow{5}{*}{0.895} & \multirow{5}{*}{0.629} \\
\hline & CI 2 & & 0.808 & & \\
\hline & CI 3 & & 0.812 & & \\
\hline & CI 4 & & 0.784 & & \\
\hline & CI 5 & & 0.767 & & \\
\hline \multirow{7}{*}{ Employee Management } & EM 1 & \multirow{7}{*}{0.874} & 0.799 & \multirow{7}{*}{0.903} & \multirow{7}{*}{0.571} \\
\hline & EM 2 & & 0.788 & & \\
\hline & EM 3 & & 0.726 & & \\
\hline & EM 4 & & 0.788 & & \\
\hline & EM 5 & & 0.764 & & \\
\hline & EM 6 & & 0.761 & & \\
\hline & EM 7 & & 0.653 & & \\
\hline \multirow{6}{*}{ Process Management } & PM 1 & \multirow{6}{*}{0.859} & 0.668 & \multirow{6}{*}{0.895} & \multirow{6}{*}{0.589} \\
\hline & PM 2 & & 0.770 & & \\
\hline & PM 3 & & 0.753 & & \\
\hline & PM 4 & & 0.841 & & \\
\hline & PM 5 & & 0.767 & & \\
\hline & PM 6 & & 0.796 & & \\
\hline \multirow{8}{*}{ Operational performance } & OP 1 & \multirow{8}{*}{0.882} & 0.660 & \multirow{8}{*}{0.907} & \multirow{8}{*}{0.551} \\
\hline & OP 2 & & 0.759 & & \\
\hline & OP 3 & & 0.668 & & \\
\hline & OP 4 & & 0.681 & & \\
\hline & OP 5 & & 0.769 & & \\
\hline & OP 6 & & 0.775 & & \\
\hline & OP7 & & 0.807 & & \\
\hline & OP8 & & 0.800 & & \\
\hline
\end{tabular}




\begin{tabular}{|c|c|c|c|c|c|}
\hline \multirow{9}{*}{ Competitive Advantage } & CA 1 & \multirow{9}{*}{0.883} & 0.708 & \multirow{9}{*}{0.906} & \multirow{9}{*}{0.519} \\
\hline & CA 2 & & 0.688 & & \\
\hline & CA 3 & & 0.795 & & \\
\hline & CA 4 & & 0.747 & & \\
\hline & CA 5 & & 0.782 & & \\
\hline & CA 6 & & 0.734 & & \\
\hline & CA 7 & & 0.719 & & \\
\hline & CA 9 & & 0.719 & & \\
\hline & CA 13 & & 0.656 & & \\
\hline \multirow{5}{*}{ TQM } & Top management & \multirow{5}{*}{0.941} & 0.812 & \multirow{5}{*}{0.891} & \multirow{5}{*}{0.620} \\
\hline & Customer Focus & & 0.790 & & \\
\hline & Continuous important & & 0.790 & & \\
\hline & Employee Management & & 0.804 & & \\
\hline & Process Management & & 0.748 & & \\
\hline
\end{tabular}

\subsubsection{Discriminant Validity}

Discriminant validity is confirmed when the correlation value between constructs is less than the value of the AVE value. This indicates that the value must be more than other values off-diagonal values in its respective column and row in the correlation matrix [72]. The current study relied mainly on [73] to prove the discriminatory validity.
In Table 2 below can be seen the results of Fornell and Larcker as a diagonal line of elements representing the square roots of AVE correlated with the structures below. Therefore, it is possible to compare those diagonal lines and beyond. Italic values are greater than others in row and column values.

Table 2. Correlations of Discriminant Validity

\begin{tabular}{|l|r|r|r|r|r|l|l|}
\hline & CA & \multicolumn{1}{l|}{ CI } & \multicolumn{1}{l|}{ CF } & EM & OP & PM & TM \\
\hline CA & 0.720 & & & & & & \\
\hline CI & 0.495 & 0.739 & & & & & \\
\hline CF & 0.524 & 0.545 & 0.741 & & & & \\
\hline EM & 0.490 & 0.524 & 0.510 & 0.756 & & & \\
\hline OP & 0.656 & 0.489 & 0.470 & 0.519 & 0.742 & & \\
\hline PM & 0.636 & 0.492 & 0.511 & 0.536 & 0.602 & 0.768 & \\
\hline TM & 0.435 & 0.610 & 0.584 & 0.543 & 0.419 & 0.417 & 0.778 \\
\hline
\end{tabular}

$\mathrm{CA}=$ competitive advantage $\mathrm{CI}=$ continuous improvement $\mathrm{CF}=$ customer focus; $\mathrm{EM}=$ employee management; $\mathrm{OP}=$ operational performance; $\mathrm{PM}=$ process management; $\mathrm{TM}=$ top management

\subsection{Confirmatory Factor Analysis Model for the Overall Measurement Model}

The current study used confirmatory factor analysis (CFA) to assess the overall measurement model including the measurement model (first and secondorder constructs) which recommended by [69].

The study model includes one higher-order construct (reflective-reflective), namely, TQM which includes five first-class structures (Top management, Customer focus, Continuous improvement, Employee management, and Process management), in addition to two first-order - reflective constructs namely (Operational performance, competitive advantage). Therefore, this study applied a two-stage approach, in firststage using the repeated indicator approach then extracting the composite reliability and average variance extracted for the higher-order construct from the first-order construct that existed in the higher-order construct.

[74] use this approach because it does not require an equal number of indices for lower-order constructs, and is also recommended when the higher-order construct is an endogenous or 
mediating variable. The Measurement model for this study was illustrated as in Fig. 2.

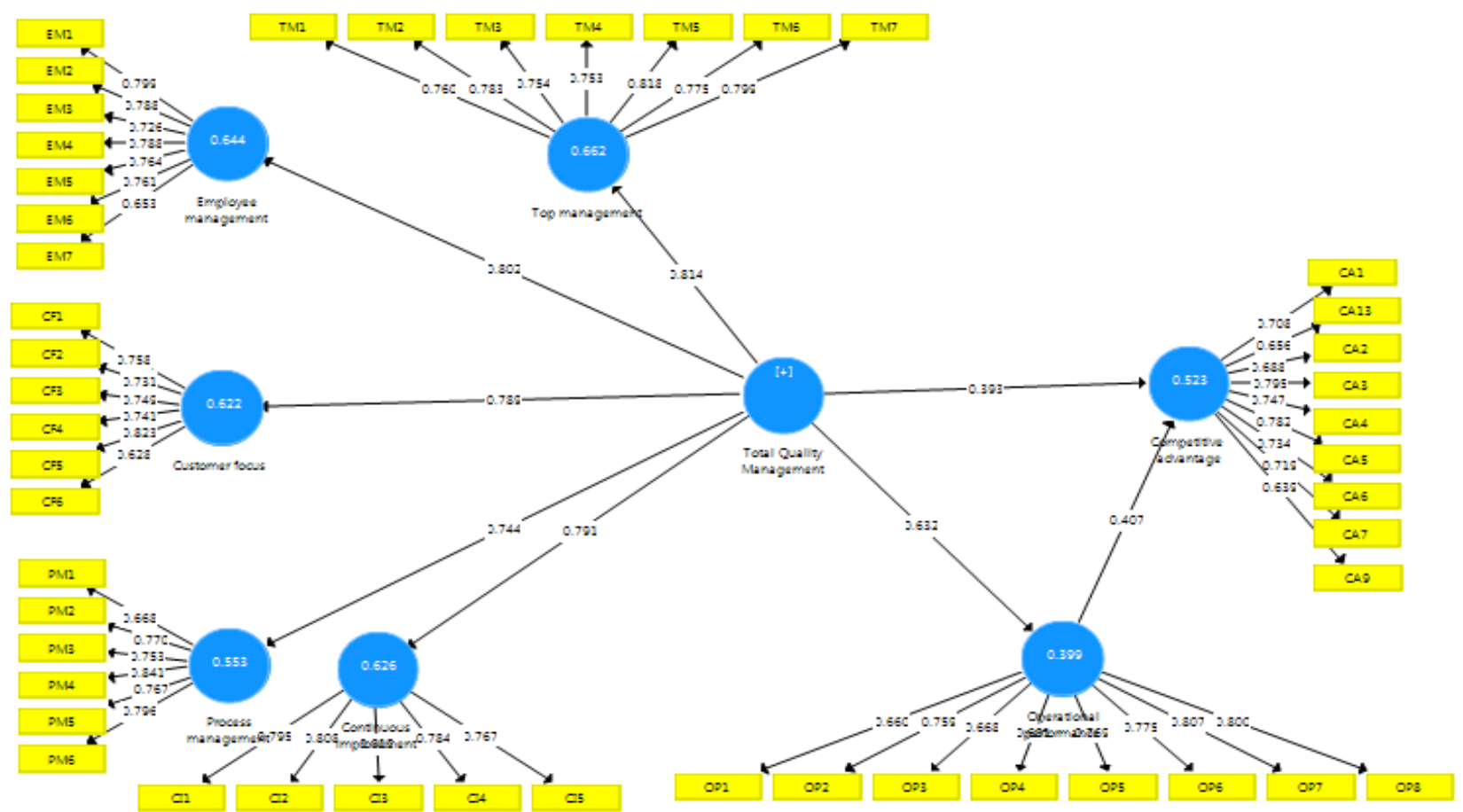

Fig. 2: Modified CFA Model for Overall Measurement Model (First Order, Second Order)

It is clear from the Fig. 2. that A CFA model was performed for 17 items which represented tow firstorder constructs (operational Performance, and Competitive Advantage) after removing the items (CA8, CA10, CA11, and CA12) which had loads less than 0.60 and were removed in line with the recommendation made by [71]. Also, the CFA model includes one second-order construct namely (TQM), The names of these five first-order constructs were Top Management, Customer Focus, Continuous Improvement, Employee Management, and Process Management, respectively using 31 items. The figure also shows the relationship between the study variables: independent, mediator and dependent. Fig. 1 is the final measurement model with acceptable outer loadings of the model constructs.

\subsection{Assessment of the Structural Model}

The next step after completing the reliability and validity of the measurement model is run and evaluate the structural model to test the study hypothesis. There are some required tests are suggested to conduct to evaluate the inner model which generally focus on the latent construct. These tests are: Coefficient of determination $\left(\mathrm{R}^{2}\right)$, effect size $\left(\mathrm{F}^{2}\right)$, predictive relevance $\left(\mathrm{Q}^{2}\right)[75]$. All of these test results were mentioned in table 3 .

\subsubsection{Hypotheses Testing}

in the current study, the proposed hypotheses were examined by using Smart PLS's Algorithm and Bootstrapping as recommended by [76]. The structural model test results are shown in Table 3

As depicted in Table 3, TQM has a positive and significant effect on the competitive advantage at the 0.001 level of significance $(\beta=0.393, t=7.113$, $\mathrm{p}<0.0001)$. TQM has a positive and significant effect on operational performance at the 0.001 level of significance $(\beta=0.632, \mathrm{t}=14.846, \mathrm{p}<0.001)$. Similarly, the effect of Operational performance on competitive advantage also was found to be positive and significant at the 0.001 level of significance $(\beta=0.407, t=7.042, p<0.001)$. Therefore, the results supported the proposed hypotheses $\mathrm{H} 1, \mathrm{H} 2$, and $\mathrm{H} 3$ as developed in this study. 
Table 3. Hypotheses Testing Result

\begin{tabular}{|l|l|l|l|l|l|l|l|l|l|}
\hline & Path shape & $\begin{array}{l}\text { Std. } \\
\text { Beta }\end{array}$ & $\begin{array}{l}\text { Std. } \\
\text { Error }\end{array}$ & T-value & $\mathrm{R}^{2}$ & $\mathrm{~F}^{2}$ & $\mathrm{Q}^{2}$ & P-value & Decision \\
\hline H1 & TQM - CA & 0.393 & 0.055 & 7.113 & 0.523 & 0.195 & 0.265 & 0.000 & Supported \\
\hline H2 & TQM - OP & 0.632 & 0.043 & 14.846 & 0.399 & 0.664 & & 0.000 & Supported \\
\hline H3 & OP - CA & 0.407 & 0.058 & 7.042 & & 0.209 & & 0.000 & supported \\
\hline
\end{tabular}

Table 3 also shows that the Coefficient of Determination $\mathrm{R}^{2}$ values of competitive advantage, and operational performance 0.523 , and 0.399 respectively, which indicates that approximately $52 \%$ of the variance in competitive advantage was explained by tow external variables (TQM, operational performance), and that approximately $40 \%$ of the variance in operational performance was explained by one predictor (TQM). In addition, the overall results showed that $\mathrm{R}^{2}$ values met the 0.19 threshold value suggested by [77].

Meanwhile, Table 3 shows that the Effect Size $\left(F^{2}\right)$ values for the three predictions on the outside are $0.195 ; 0.664 ; 0.209$, respectively, which is a medium, large, and medium effect size, respectively, as recommended by [78], indicating the extent to which the predictors explain the competitive advantage, and operational performance.
On the other hand, the Predictive Relevance of the Model $\left(\mathrm{Q}^{2}\right)$ values for competitive advantage were 0.265 and these values are above zero, indicating that the model has predictive relevance [79].

\subsubsection{Testing the Mediating Role of Operational Performance}

This study used the Preacher, and Hayes method to analyze the role of operational performance as a mediating variable in the relationship between TQM and competitive advantage. The result of bootstrapping analyses indicated as shown in Table 4 that the indirect effect of TQM on competitive advantage through operational performance was positive and statistically significant at the 0.05 level; $\beta=0.257$, t-value $=6.696, \mathrm{p}$-value $=0.000$ Also, the boot confidence interval (CI) bias-corrected did not straddle a 0 in between, indicating, as reported by [80], that there was a mediating effect; The lowest level $(\mathrm{LL})=0.187$, the highest level $(\mathrm{UL})=0.333$. This confirms that the mediation effect was statistically significant, and thus the $\mathrm{H} 4$ hypothesis was supported.

Table 4. mediation effect

\begin{tabular}{|l|l|l|l|l|l|l|l|l|}
\hline & Relationship & S. B & St. D & T-value & P-value & $\begin{array}{l}\text { LL } \\
(2.5)\end{array}$ & $\begin{array}{l}\text { UL } \\
(97.5)\end{array}$ & Decision \\
\hline H4 & TQM -OP -CA & 0.257 & 0.038 & 6.696 & 0.000 & 0.187 & 0.333 & Supported \\
\hline
\end{tabular}

\subsubsection{Predictive Relevance of the Mode}

This study is used R-squared values to assess the study model's predictive power. As a general rule, [71] determined that R-squared values of 0.75 and above, between 0.25 and 0.75 , equal to or below 0.25 to be considered as strong, moderate, and weak predictive power, respectively. In this study, the highest R-squared value was a competitive advantage $(0.523)$, followed by the operational performance (0.399) as can be seen in table 3 . These findings indicate a moderate in-sample predictive power of the study model.

\section{Discussion}

The finding demonstrated that TQM has a positive effect on competitive advantage. This can be interpreted that the participation of top management in Jordanian banks in supporting and improving the quality strategy, constantly meeting customers' needs and expectations, emphasizing continuous improvement of services provided to customers, encouraging employees, and urging them to participate in quality programs, are some of the reasonable reasons that contributed to enhancing the Competitive advantage in Jordanian banks. This 
study agrees with many previous studies that showed that TQM directly affects the competitive advantage, such as $[9,10,11,14,47,48]$.

Meanwhile, the results showed that TQM has a positive and significant effect on operational performance. This can be explained by the awareness of top management in Jordanian banks of the importance of applying quality in the various activities of banks and their business, ensuring that the demands of customers are met on time, the speed of response to customer feedback, and complaints, the participation of employees at various administrative levels in quality activities and work, the alignment between quality and cost While providing the service to customers, these may be some of the reasonable and possible reasons that contributed to the enhancement and improvement of operational performance in Jordanian banks. The results of this study are in agreement with the results of the study [34, 41, 44, 50, 51, 81] all of which emphasized TQM that directly effects on operational performance, raise its level and leads to its improvement in various organizations.

The results also showed that the operational performance has a positive and important impact on the competitive advantage in Jordanian banks. This can be interpreted that the bank management's interest in providing services at reasonable prices that suit the desires and interests of customers on time, the ability of banks to reduce the time taken to implement customers' requests, the ability of banks to provide diverse and unique services that suit customers' needs, the interest of bank employees in improving their performance and the performance of their departments, are reasonable reasons to improve the competitive advantage in Jordanian banks. The result of this study agreed with the results of the studies of $[53,54,82,83]$, which emphasized that operational performance has a positive effect and leads to the improvement of competitive advantage.

The result also showed that operational performance is a mediator between TQM and competitive advantage in Jordanian banks. This result can be explained by the fact that the operational performance appears through the keenness of the management of Jordanian banks to meet the needs and desires of customers by providing flexible and diversified high-level services at the specific time, and the keenness of the management of banks and employees to adopt the TQM as a long-term strategy and its application in various administrative levels, each This helps to improve the competitive advantage. The results of this study agreed with the results of studies by $[56,57,58,59]$, which all indicated that the operational performance It acts as a mediator between many different variants.

\section{Limitations and Directions for Future Research}

This study contains two important limitations; these limitations are: Firstly, this study used a crosssectional design, which does not allow monitoring the changes that may have occurred over time. Therefore, conducting a longitudinal study will help to overcome this limitation, treat it and confirm the result. The longitudinal study will also provide a deeper understanding of the mutual influence between the study variable. Secondly, this study dealt with the direct effects of TQM on competitive advantage, as well as the indirect impact of TQM on competitive advantage through operational performance as mediating variable.

Future studies can address these relations within other economic sectors such as the private hospital sector, the telecommunications sector, and the industrial sector. Comparative studies can also be conducted using the same study variables, but in different sectors, providing further understanding about the potential relationships of such studies.

\section{Conclusion}

This study provided empirical evidence for the direct effect of TQM on competitive advantage and operational performance. It also provided empirical evidence for the role of operational performance as a mediating variable in the relationship between TQM and competitive advantage. The structural model supports the direct impact of TQM on competitive advantage and the indirect impact of TQM on competitive advantage through operational performance. This study contributes to providing evidence that may help to enhance understanding and knowledge of the relationship between TQM, operational performance, and competitive advantage. It also contributes to bridging the knowledge gap regarding the lack of studies dealing with the relationship between TQM and competitive advantage Through the theoretical framework it presents, the results of this study are also, important to researchers and academics as they constitute the nucleus for further research. From a methodological point of view, this study may help, through the framework provided by it, to clarify the relationship between its variables. The use of smart PLS may lead to unique and unknown insights regarding the impact of various factors on competitive advantage. 
From a practical perspective, the results of this study are likely to be useful in making administrative decisions related to developing capabilities that generate a competitive advantage.

\section{References:}

[1] Qasrawi, S. T., ALmahamid, A. M., Maghraby, K. M.\& Qasaroi, A. T., The Impact Competitive Priorities on Organizational Performance: Testing the Mediating Role of Enterprise Resource Planning System (ERP) Usage and E-Business Adoption: An Empirical Study: In Arab Bank's Branches in Amman City. Jordan Journal of Business Administration, 12, (3), 2016, 347-375.

[2] Nour, A. \&, Bastanji, A. M., The role of the Central Bank of Jordan in reducing the repercussions of the financial crisis to the banks operating in Jordan, the Jordanian Journal of Business Administration, 9 (2), 2013, 356-371.

[3] Abu Wadi, R. M, \& SaqfAl-Hayt, N. A, Determinants of Jordanian banking industry performance. Jordan Journal of Business Administration, 13(2), 2017,181-199.

[4] Association of Banks in Jordan (2017). Annual report of the Association of Banks in Jordan in 2017. Retrieved from: http://www.abj.org.jo/enus/annualreports.aspx

[5] Mohamed, H. A., Effect of TQM Practices On Competitive Advantage of Transport and Logistics Firms in Mombasa County, Kenya (Doctoral Dissertation, School of Business, University of Nairob, 2016.

[6] Addae-Korankye, A., TQM (TQM): a source of competitive advantage. a comparative study of manufacturing and service firms in Ghana. International Journal of Asian Social Science, 3(6), 2013,1293-1305.

[7] Azzam, Z., Ali, M. W., LShaikh, M., Khanfar, I., \& Ismai, A. R. Factors Affecting the Use of Electronic Banking Services Provided by Jordanian Commercial Banks from Customers' Point of View. A Case Study: Jordan Ahli Bank in Northern Region/Jordan. In 2021 22nd International Arab Conference on Information Technology (ACIT), 2021, (December) ,pp. 112.

[8] Yunis, M., Jung, J., \& Chen, S., TQM, strategy, and performance: a firm- level analysis. International Journal of Quality \& Reliability Management. Vol. 30 No. 6, 2013, pp. 690-714.

[9] Ahmed, A., \& Ferdousi, F, TQM components as a source of competitive advantage in a beverage organization: a resource based view. International Journal of Business Strategy and Automation (IJBSA), 1(2), 2020, 25-36.

[10] Othman, B., Khatab, J. J., Esmaeel, E. S., Mustafa, H. A., \& Sadq, Z. M., The Influence of TQM on Competitive Advantage towards Bank Organizations: Evidence from Erbil/Iraq. International Journal of Psychosocial Rehabilitation, 24(5), 2020, 3427-3439.

[11] Pinandhita, G., and Y. Latief. "Implementation strategy of total quality management and quality culture to increase the competitiveness of contractor companies in Indonesia." IOP Conference Series: Materials Science and Engineering. Vol. 930. No. 1. IOP Publishing, 2020.

[12] Chen, R., Lee, Y. D., \& Wang, C. H., TQM and sustainable competitive advantage: serial mediation of transformational leadership and executive ability. TQM \& Business Excellence, 31(5-6), 2020, 451-468.

[13] Ferdousi, F., Baird, K., Munir, R., \& Su, S., Associations between organizational factors, TQM and competitive advantage: Evidence from an emerging economy. Benchmarking: An International Journal, 25(3), 2018,854-873.

[14] Mawarti, A. R., Effect of External Environment Organization and Application of TQM (TQM) And Performance of the Company and Its Effect On Competitive Advantage in Ptism Bogasari Flourmills, Jakarta. Jrmsi-Jurnal Riset Manajemen Sains Indonesia, 7(1), 2016, 22-40.

[15] Evelyn, U. Total quality management as a competitive advantage for small and medium scale enterprises in Nigeria. nkumba business journal, volume (18), 2021.

[16] Dow, D., Samson, D., \& Ford, S., Exploding the myth: do all quality management practices contribute to superior quality performance? Production and operations management, 8(1),1999, 1-27.

[17] Wibowo, S. S. A., \& Adisty, F. Y., Analysis of TQM on Competitive Performance of Oil and Gas Industry. Journal of Applied Accounting and Taxation, 2(1), 2017, 22-30.

[18] Abdullah, M. M. B., \& Tarí, J. J., Hard quality management and performance: the moderating role of soft quality management. International Journal for Quality Research 11(3), 2017, pp. 587-602.

[19] O’Neill, P., Sohal, A., \& Teng, C. W., Quality management approaches and their impact on firms' financial performance-An Australian 
study. International Journal of Production Economics, 171, 2016, 381-393.

[20] García-Bernal, J., \& Ramírez-Alesón, M., Why and how TQM leads to performance improvements. Quality Management Journal, 22(3), 2015, 23-37.

[21] Pereira-Moliner, J., Pertusa-Ortega, E. M., Tarí, J. J., López-Gamero, M. D., \& Molina-Azorín, J. F., Organizational design, quality management and competitive advantage in hotels. International Journal of Contemporary Hospitality Management, 28(4), 2016,762-784.

[22] Pérez, V. F., \& Gutiérrez Gutiérrez, L., External managerial networks, strategic flexibility and organizational learning: a comparative study among non-QM, ISO and TQM firms. TQM \& Business Excellence, 24(3-4), 2014, 243-258.

[23] Ladipo, P. K. A., Arebi, I. T., Akeke, O. S., \& Bisiriyu, B. (2021). Effect of Customer Service On Corporate Competitive Advantage in The Nigerian Telecoms Service Industry. Management and Marketing Journal, 19(2), 2021 212-229.

[24] Afraz, M. F., Bhatti, S. H., Ferraris, A., and Couturier, J. The impact of supply chain innovation on competitive advantage in the construction industry: Evidence from a moderated multi-mediation model. Technological Forecasting and Social Change, 162, (2021), 120370.

[25] Mentzer, J. T., Min, S., \& Zacharia, Z. G., The nature of interfirm partnering in supply chain management. Journal of retailing, 76(4), 2000, 549-568.

[26] Putra, F. R., Abdillah, R., \& Putri, K. T. Understanding Strategic Initiatives Contributing to The Implementation of Cost Leadership and Differentiation Strategy to Achieve Competitiveness: A Case Study of Indonesia's Cement Industry. Proceedings of the 4th European International Conference on Industrial Engineering and Operations Management Rome, Italy, August 2-5, 2021

[27] Falahatgar, S., Chamanzamin, M. R., \& Taleghani, M, The Effect of Competitive Advantage Strategies on Customer Loyalty: Mediated role of Brand Identification and Brand Awareness (Case study: Parsian Insurance customers). Journal of System Management, 7(4), 2021, 229-252.

[28] Alfalla-Luque, R., Machuca, J. A., \& MarinGarcia, J. A, Triple-A and competitive advantage in supply chains: Empirical research in developed countries. International Journal of Production Economics, 2018, 203, 48-61.

[29] Aboelmaged, M., The drivers of sustainable manufacturing practices in Egyptian SMEs and their impact on competitive capabilities: A PLS-SEM model. Journal of Cleaner Production, 2018, 175, 207-221.

[30] Huang, Z., Pei, X., Xi, J., Othman, B., Ali, S., \& Lin, L. The Influence of Consumers' Perception on Perceived Value and Purchase Intention with respect to Regional Products Based on a CAB Model. Tekstilec, 62(3), 2019, 219-228.

[31] Balamurugan, S. TQM-Integrated Process Approach for Continuous Improvement of Projects in Engineering. Available at SSRN 3767545, 2021.

[32] Gonzalez-Padron, T., Akdeniz, M. B., \& Calantone, R. J., Benchmarking sales staffing efficiency in dealerships using extended data envelopment analysis. Journal of Business Research, 67(9), 2014, 1904-1911.

[33] Hua, N., \& Lee, S., Benchmarking firm capabilities for sustained financial performance in the US restaurant industry. International Journal of Hospitality Management, 36, 2014, 137-144.

[34] Adem, M. K., \& Virdi, S. S., The effect of TQM practices on operational performance: an empirical analysis of ISO 9001: 2008 certified manufacturing organizations in Ethiopia. The TQM Journal, Vol. 33 No. 2, 2020, pp. 407440.

[35] Talib, F., Rahman, Z. and Qureshi, MN., The relationship between total quality management and quality performance in the service industry: a theoretical model, International Journal of Business, Management and Social Sciences (IJBMSS), MultiCraft, 1(1), 2010, 113-128.

[36] Talib, F., Rahman, Z., \& Qureshi, M. N., An empirical investigation of relationship between total quality management practices and quality performance in Indian service companies. International journal of quality \& reliability management, 30(3), 2013, 280-318.

[37] Nguyen, M. H., Phan, A. C., \& Matsui, Y. Contribution of Quality Management Practices to Sustainability Performance of Vietnamese Firms. Sustainability, 10(2), (2018) 375-389.

[38] Bani-Hani, J. S., \& Al-Omari, Z., The role of quality improvement factors in improving quality based operational performance: Applied study in private hospitals in Jordan. 
International Journal of Business and Social Science, 3(18), 2021, pp. 213-222

[39] Senarath, B. T. D. N., Gunarathne, G. C. I., \& Fernando, T. S. S. Impact of Total Quality Management on Operational Performance. Peradeniya Management Review - Volume II Issue 1 (June) 2020,pp 98-131.

[40] Barre, V., Ramos, D. O., Medovich, C., Lovera, G., \& Hoch, M. Building a sustainable high-performance customer experience and product performance (CxPP): the JJV experience. The TQM Journal Volume 33 Issue 8, 2021.

[41] Saleh, R. A., Sweis, R. J., \& Saleh, F. I. M., Investigating the impact of hard TQM practices on operational performance in manufacturing organizations: Evidence from Jordan. Benchmarking: An International Journal. Vol. 25 No. 7, 2018, pp. 2040-2064.

[42] Pono, M., \& Munizu, M., The role of company competitiveness as mediation variable the impact of supply chain practices on operational performance. Uncertain Supply Chain Management, 9(1), 2021, 125-132.

[43] Tarigan, Z., Mochtar, J., Basana, S., \& Siagian, H., The effect of competency management on organizational performance through supply chain integration and quality. Uncertain Supply Chain Management, 9(2), 2021, 283-294.

[44] Modgil, S., \& Sharma, S., Total productive maintenance, TQM and operational performance: An empirical study of Indian pharmaceutical industry. Journal of Quality in Maintenance Engineering. Vol. 22 No. 4, 2016, pp. 353-377.

[45] Sadq, Z. M., Mohammed, H. O., Othman, B., \& Saeed, V. S. Attitudes of Managers in the Knowledge Private University towards the impact of Human Capital in Achieving Competitive Advantages. TEST Engineering and Management, 82, 2020, 393-401.

[46] Abdulameer, O. A., The Role of Total Quality Management in Achieving Competitive Advantage. Psychology and Education Journal, 58(4), 2021, 2919-2935.

[47] Abimbola, B. O., Oyatoye, E. O., \& Oyenuga, O. G., Total quality management, employee commitment and competitive advantage in Nigerian tertiary institutions. A study of the University of Lagos. International Journal of Production Management and Engineering, 8(2), 2020, 87-98.

[48] Yanya, M., \& Mahamat, N., The impact of supply chain management practices on competitive advantages: moderation role of
TQM. Polish Journal of Management Studies, Vol. 21, No. 1.,2020, pp. 419-431.

[49] Gelan, E. D., \& Dange, M. A. The Effect of Total Quality Management on Operational Performance in Manufacturing Industries in Dire Dawa, Ethiopia. Glob Acad J Econ Buss, 3(1), ,2021, 28-48.

[50] Pal, S. (2016). An empirical study of TQM (TQM) practices on operational performance of Indian manufacturing and service firms. International Journal of Management (IJM), 7(6), 2016, PP. 192-200.

[51] Kiprotich, A. M., Njuguna, R., \& Kilika, J., TQM Practices and Operational Performance of Kenya Revenue Authority, International Journal of Contemporary Aspects in Strategic Management (IJCASM), 2, (I), 2018, 91-105.

[52] Aboelmaged, M. G., Linking operations performance to knowledge management capability: the mediating role of innovation performance. Production Planning \& Control, 2014, 25(1), 44-58.

[53] Iranmanesh, M., Kumar, K. M., Foroughi, B., Mavi, R. K., \& Min, N. H. The impacts of organizational structure on operational performance through innovation capability: innovative culture as moderator. Review of Managerial Science, 15(7), 2021, 1885-1911.

[54] Youssef, M. A., \& Youssef, E. M., The synergistic impact of ISO 9000 and TQM on operational performance and competitiveness. International Journal of Quality \& Reliability Management, 35(3), 2018, 614-634.

[55] Del Alonso-Almeida, M. M., Bagur-Femenías, L., \& Llach, J.,The adoption of quality management practices and their impact on business performance in small service companies: the case of Spanish travel agencies. Service Business, 9(1), 2015, 57-75.

[56] Anil, A. P., \& Satish, K. P., TQM practices and its performance effects-an integrated model. International Journal of Quality \& Reliability Management, Vol. 36 No. 8, 2019, pp. 1318-1344.

[57] Kharub, M., \& Sharma, R., An integrated structural model of QMPs, QMS and firm's performance for competitive positioning in MSMEs. TQM \& Business Excellence, 31(3-4), 2020, 312-341.

[58] Bendickson, J. S., \& Chandler, T. D., Operational performance: The mediator between human capital developmental 
programs and financial performance. Journal of Business Research, 94, 2019, 162-171.

[59] Chang, W., Ellinger, A. E., Kim, K. K., \& Franke, G. R., Supply chain integration and firm financial performance: A meta-analysis of positional advantage mediation and moderating factors. European Management Journal, 34(3), 2016, 282-295.

[60] Mang'eli, G. M. \& Kilika, J., TQM practices and operational performance of Nairobi Bottlers Limited, Kenya. International Academic Journal of Human Resource and Business Administration, 3(3), 2018, 356-374

[61] Jimoh, R., Oyewobi, L., Isa, R., \& Waziri, I., TQM practices and organizational performance: the mediating roles of strategies for continuous improvement. International Journal of Construction Management, 19(2), 2019,162-177.

[62] Cooper, DR. \& Schindler, PS, Business Research Methods, 12th edition Mc. Graw Hill Irwin, 2014

[63] Sekaran, U., \& Bougie, R., Research methods for business: A skill building approach. John Wiley \& Sons, 2016.

[64] Hair, J. F., Wolfinbarger, M. F., \& Ortinall, D. J., Essential of marketing Research, 2008.

[65] Molina-Azorín, J. F., Tarí, J. J., PereiraMoliner, J., López-Gamero, M. D., \& PertusaOrtega, E. M., The effects of quality and environmental management on competitive advantage: A mixed methods study in the hotel industry. Tourism Management, 50, 2015, 4154.

[66] Nyamari, P. M., Effect of Total Quality Management Practices On Operational Performance of Commercial Banks in Mombasa County, Kenya (Doctoral Dissertation, University of Nairobi), 2017.

[67] Henseler, J., Ringle, C. M., \& Sarstedt, M. A new criterion for assessing discriminant validity in variance-based structural equation modeling. Journal of the academy of marketing science, 43(1), 2015. 115-135.

[68] Cheah, J. H., Sarstedt, M., Ringle, C. M., Ramayah, T., \& Ting, H., Convergent validity assessment of formatively measured constructs in PLS-SEM. International Journal of Contemporary Hospitality Management, Vol. 30 No. 11, 2018, pp. 3192-3210.

[69] Hair, J. F., Black, W. C., Babin, B. J., \& Anderson, R. E., Multivariate data analysis (7th ed.). Upper Saddle River, New Jersey: Prentice Hall, 2010.
[70] Huang, C. C., Wang, Y. M., Wu, T. W., \& Wang, P. A., An empirical analysis of the antecedents and performance consequences of using the Moodle platform. International Journal of Information and Education Technology, 3(2), 2013, 217.

[71] Hair Jr, J. F., Hult, G. T. M., Ringle, C., \& Sarstedt, M., A primer on partial least squares structural equation modelling (PLS-SEM). Loss Angeles, CA: Sage publications, 2017.

[72] Fornell, C., \& Bookstein, F. L., Two structural equation models: LISREL and PLS applied to consumer exit-voice theory. Journal of Marketing research, 19(4), 1982, 440-452.

[73] Fornell, C., \& Larcker, D. F., Evaluating structural equation models with unobservable variables and measurement error. Journal of marketing research, 18(1), 1981, 39-50.

[74] Sarstedt, M., Hair Jr, J. F., Cheah, J. H., Becker, J. M., \& Ringle, C. M. (2019). How to specify, estimate, and validate higher-order constructs in PLS-SEM. Australasian Marketing Journal (AMJ), 27(3), 197211.Hufit, Ringle, \& Sarstedt, 2017.

[75] Hair, J. F., Hult, G. T. M., Ringle, C., \& Sarstedt, M. A primer on partialleast squares structural equation modeling (PLS-SEM). Washington, DCSage Publications, 2014.

[76] Felsenstein, J., Confidence limits on phylogenies: an approach using the bootstrap. evolution, 39(4), 1985, 783-791.

[77] Chin, W.W. The partial least squares approach to structural equation modeling. Modern methods for business research, 295(2), 1998, PP. 295-336.

[78] Draper, S., Effect size. Retrieved Feb, 27, 2018.

[79] Chin, W. W. How to write up and report PLS analyses in V. Vinzi, W.W. Chin, J. Henseler, $\&$ H. Wang (Eds.), Handbook of partial least squares (pp. 655-690). New York: Springer. 2010.

[80] Preacher, K. J., \& Hayes, A. F., Asymptotic and resampling strategies for assessing and comparing indirect effects in multiple mediator models. Behavior research methods, 40(3), 2008, 879-891.

[81] Chaudhry, N. I., Awan, M. U., Bilal, A., \& Ali, M. A., Impact of TQM On Organizational Performance: The Mediating Role of Business Innovativeness and Learning Capability. Journal of Quality and Technology Management, 15(1), 2018, 1-36.

[82] Hilmersson, M. (2014). Small and mediumsized enterprise internationalization strategy 
and performance in times of market turbulence. International Small Business Journal, 32(4), 2014, 386-400.

[83] Terziovski, M., \& Guerrero, J. L., ISO 9000 quality system certification and its impact on product and process innovation performance. International Journal of Production Economics, 158, 2014, 197-207.

\section{Creative Commons Attribution License 4.0}

(Attribution 4.0 International, CC BY 4.0)

This article is published under the terms of the Creative Commons Attribution License 4.0

https://creativecommons.org/licenses/by/4.0/deed.en US 